\title{
PENDAMPINGAN BELAJAR DI RUMAH BERBASIS KARAKTER DENGAN NILAI-NILAI RELIGIUS PADA MASA PANDEMIK COVID 19
}

\author{
Imam Mawardi ${ }^{1}$, Tri Wahyu Arissanti ${ }^{2}$, Anif Magfiroh $^{3}$, Risma Zuliyana $^{4}$, \\ Ulfa Berta Audina ${ }^{5}$, Fifin Anis Astutik ${ }^{6}$. \\ 1, 2,3,4 Pendidikan Agama Islam, Fakultas Agama Islam \\ ${ }^{5,6}$ Pendidikan Guru SD, Fakultas Keguruan dan Ilmu Pendidikan \\ Universitas Muhammadiyah Magelang \\ Email: mawardirazal @ummgl.ac.id
}

\begin{abstract}
The importance of character is at the forefront of education, but during the Covid 19 period character education could not be optimally internalized to students. This causes the learning formulation to shift from school to home and neglect of character values in learning. Of course, realities like this require parents to have a role not only in controlling in terms of learning, but also paying attention to character, even though not all parents have pedagogical abilities. Therefore, the purpose of the PPMT program is to assist parents in accompanying character-based student learning with religious values at home. The scope of special activities for the children of the Dusun Penggaron Kidul. The method used by Participatory Rural Aprqissal (PRA) is divided into three stages, namely preparation, implementation, and report preparation. The results of the PPMT program are community assistance in solving children's learning problems and the existence of a pocketbook guide for home tutoring based on religious characters that makes it easier to accompany learning during the Covid 19 pandemic.
\end{abstract}

Keywords: Learn mentoring, study at home, religious character, covid 19

\begin{abstract}
Abstrak. Pentingnya karakter menjadi ujung tombak dalam pendidikan, namun dalam masa covid 19 pendidikan karakter tidak bisa optimal diinternalisasikan kepada peserta didik. Hal ini menyebabkan formulasi pembelajaran beralih dari sekolah ke rumah dan terabaikannya nilai-nilai karakter dalam pembelajaran. Tentunya realitas seperti ini menuntut orang tua berperan tidak hanya mengontrol dalam hal belajar, tetapi juga memperhatikan karakter, padahal tidak semua orangtua mempunyai kemampuan pedagogik. Oleh sebab itu tujuan dari program PPMT ini adalah membantu orangtua dalam mendampingi belajar siswa berbasis karakter dengan nilai-nilai religius di rumah. Lingkup kegiatan khusus untuk anakanak masyarakat Dusun Penggaron Kidul. Metode yang digunakan Participatory Rural Apraissal (PRA) yang dibagi menjadi tiga tahap yaitu persiapan, pelaksanaan, dan penyusunan laporan. Hasil dari program PPMT adalah terbantunya masyarakat dalam pemecahan masalah belajar anak dan adanya buku saku panduan bimbingan belajar di rumah berbasis karakter religius yang memudahkan dalam mendampingi belajar di masa pandemic covid 19.
\end{abstract}

Kata Kunci: Pendampingan belajar, belajar di rumah, karakter religius, covid 19

\section{PENDAHULUAN}

Pandemi Covid-19 dan penyebarannya secara global telah merubah aspek-aspek kehidupam dalam semua dimensi yang berdampak kepada aktivitas masyarakat khususnya di bidang yang sangat fundamental yaitu pendidikan. Sebagaimana disinyalir UNICEF, WHO dan IFRC dalam COVID-19 Prevention and Control in Schools (Maret, 2020) menyebutkan situasi penyebaran virus yang cepat maka kegiatan pembelajaran langsung di sekolah harus dihentikan. dan diganti kegiatan pembelajaran daring dengan menggunakan berbagai media. Data UNESCO (2020) menyebut
1,5 miliar siswa dan 63 juta guru di tingkatan sekolah dasar hingga menengah di 191 negara yang terdampak pandemi Covid-19, sesuatu yang tidak pernah terjadi sebelumnya (Gugus Tugas Covid 19, 2020). Akibat kebijakan penghentikan belajar langsung di sekolah dan diganti sistem daring atau lainnya, ada hal yang sering luput untuk diperhatikan yaitu tentang penguatan pendidikan karakter yang tentunya proses internalisasi akan mengalami hambatan di masa pandemic covid 19. Beberapa penelitian telah dilakukan, seperti yang dilakukan Sabiq (2020); Suyadi, dkk (2020); dan Pujilestari (2020). Meskipun dalam tataran implementasi 
pengauatan karakter di masa covid 19 belum dapat perhatian secara baik.

Kebijakan pemerintah bahwa pendidikan di semua level jenjang pendidikan harus tetap berjalan, meskipun pelaksanaan proses pembelajaran tidak dilakukan di sekolah tetapi di rumah. Peran serta orang tua sangat diperlukan dalam mendampingi siswa saat belajar dirumah, karena jika tidak dikontrol oleh orang tua maka proses belajar di rumah tidak akan berjalan sebagaimana mestinya. Namun dalam proses pelaksanaannya orang tua mendapat beberapa kendala. Beberapa analisis situasi dari persoalan umum yang dihadapi orang tua yang tinggal di desa tentang belajar di rumah dapat digambarkan sebagai berikut; (1) Jam belajar bersamaan dengan jam orangtua bekerja, sehingga orang tua tidak bisa secara optimal mendampingi belajar anak; (2) Tidak semua orang tua paham dengan mata pelajaran yang dibelajarkan kepada anak; (3) Koneksi internet yang seringkali tidak stabil sehingga menghambat proses pembelajaran daring; (4) Anak susah fokus dan kurang faham dalam mengerjakan tugas dari apa yang disampaikan guru baik lewat daring atau mengambil materi tugas dari sekolah; apalagi bentuk tugas terasa monoton dan tidak bisa menampilkan pembekajaran yang aktif, kreatif, efektif dan menyenangkan; (5) Internalisasi nilai karakter dengan nilai-nilai religious pada setiap mata pelajaran tidak optimal ditularkan dan dibiasakan kepada siswa tanpa pembelajaran langsung. Masalah yang kelima ini menjadi fokus prioritas masalah pendidikan di program PPMT.

Dari permasalahan belajar di rumah akibat dampak covid 19 ini, dengan menggandeng mitra Pimpinan Ranting Muhammadiyah Dusun Penggaron Kidul, alternatif solusi dari program PKMT ini yaitu: (1) Sosialisasi untuk orang tua wali murid tentang pentingnya pendidikan karakter yang mengiringi proses pembelajaran di rumah dengan nilai-nilai religius di musim covid 19, (2) Penyusunan buku saku panduan bimbingan belajar di rumah berbasis karakter religious, (3) Bimbingan kepada mitra PRM Penggaron Kidul tentang penerapan internalisasi Karakter,
Pendampingan belajar di rumah untuk siswa berbasis karakter dan nilai-nilai religius.

Pentingnya karakter dalam formulasi pembelajaran di rumah di masa covid 19 ini bagi orang tua khususnya, tidak hanya mengontrol dalam hal belajar, tetapi juga harus memperhatikan karakter anak dengan berpedoman pada nilai-nilai religius. Karena jika dalam bersekolah anak mungkin dapat dikontrol guru dalam belajar, perilaku maupun keagamaanya, namun pada kondisi pandemi saat ini orang tua lah yang harus mengontrol anak tersebut. Karena tidak hanya ilmu pengetahuanya saja yang baik tetapi karakter dan keagamaan anak juga harus baik. Adapun suatu cara untuk menanamkan perilaku dan keyakinana dalam diri anak adalah melalui pembiasaan-pembiasaan serta menciptakan lingkungan yang mendukung anak agar lebih bermoral dan berkarakter religius sehingga dapat membentuk anak-anak yang islami.

Berdasarkan uraian tersebut, pendampingan belajar di rumah dalam musim pandemi covid 19 ini menjadi sangat penting yang bertujuan membantu masyarakat memecahkan problematika pendidikan di dusun Penggaron Kidul, terutama terabaikannya nilai karakter dan religius yang terinternalisasi dalam pembelajaran. Oleh karena itu secara khusus pengabdian masyarakat ini bertujuan (1) mensosialisasikan pentingnya pendidikan karakter di masa covid 19 untuk orang tua wali murid, (2) menyusun buku saku panduan bimbingan belajar di rumah berbasis karakter religious, (3) memberi pendampingan belajar di rumah untuk siswa berbasis karakter dan nilainilai religius, (4) membantu TPQ dalam Baca Tulis Alquran (BTQ) pada TPQ sebagai pendukung penguatan internalisasi karakter.

Bentuk pendampingan belajar di rumah berkarakter dengan nilai-nilai religius adalah sebuah pendampingan terhadap belajar siswa di rumah pengganti belajar di sekolah dengan tetap membiasakan nilai-nilai karakter dan sikap religius siswa yang di masa covid 19 ini terasa terabaikan. Dengan demikian kegunaan program ini dapat menjadi menjadi alternatif model pendidikan dalam menumbuhkembangkan karakter anak belajar di rumah pada musim covid 
19. Hal ini untuk menjawab permasalahan tentang internalisasi karakter dari kondisi pembelajaran di musim covid 19. Adapun target akhir dari program ini adalah tercapainya pendampingan belajar berkarakter di rumah dengan penguatan kader mitra masyarakat melalui Pimpinan Ranting Muhammadiyah Dusun Penggaron Kidul, Sawangan, Magelang. Luaran dari program ini telah dihasilkan satu artikel di jurnal pengabdian masyarakat (Sinta 4), buku saku pedoman belajar di masa covid, publikasi kegiatan di media massa dan di cannel you tube.

\section{METODE PELAKSANAAN}

Metode yang digunakan dalam pelaksanaan kegiatan PKMT adalah metode pemberdayaan masyarakat partisipatif atau Participatory Rural Apraissal (PRA), dengan menekankan pada keterlibatan masyarakat dalam keseluruhan kegiatan yang dilaksanakan. Masyarakat dalam hal ini adalah orang tua wali murid dan mitra Pimpinan Ranting Muhammadiyah (PRM). Mitra PRM ini sebagai pengelola amal usaha pendidikan formal Madrasah Ibtidaiyah dan juga memiliki tanggung jawab moral di level kemasyarakatan. Oleh karena itu keterlibatan mitra dalam penentuan pemecahan masalah dan penyelesaiannya mampu memberikan kontribuasi yang positif dalam mengawal program pendampingan belajar saat covid 19.

Lokasi kegiatan PPMT Dusun Penggaron Kidul, Desa Gondowangi, Kecamatan Sawangan, Kabupaten Magelang. Seluruh rangkaian kegiatan telah dilaksanakan secara komprehesif selama dua bulan dengan tahapan kegiatan dan target capaian pelaksanaan pengabdian masyarakat sebagaimana terlihat dalam tabel 1:

Tabel 1. Tahapan Metode Pelaksanaan Pengabdian Masyarakat

\begin{tabular}{|c|c|c|}
\hline Tahap & Kegiatan & Target capaian \\
\hline Persiapan & $\begin{array}{l}\text { - Identifikasi dan pemetaan masalah mitra } \\
\text { dengan FGD } \\
\text { - Menyusun proposal } \\
\text { - Mengurus perizinan } \\
\text { - Jadwal kegiatan dan Job deskripsi }\end{array}$ & $\begin{array}{l}\text { - Proposal } \\
\text { - Perizinan pelaksanaan } \\
\text { - Jadwal kegiatan } \\
\text { - Job deskripsi anggota }\end{array}$ \\
\hline \multirow[t]{4}{*}{ Pelaksanaan } & $\begin{array}{l}\text { Kegiatan } 1 \\
\text { Sosialisasi untuk orang tua wali murid } \\
\text { tentang pentingnya pendidikan karakter di } \\
\text { masa covid } 19\end{array}$ & $\begin{array}{l}\text { - Peningkatan pemahaman orang tua } \\
\text { tentang pentingnya pendidikan karakter } \\
\text { dengan nilai-nilai religius bagi anak } \\
\text { - Partisipasi aktif peserta } 90 \%\end{array}$ \\
\hline & $\begin{array}{l}\text { Kegiatan } 2 \\
\text { Penyusunan buku saku panduan bimbingan } \\
\text { belajar di rumah berbasis karakter religious }\end{array}$ & $\begin{array}{l}\text { - Tersusunnya buku saku sebagai } \\
\text { pedoman pembelajaran di masa covid } \\
\text { - Target tercapai } 100 \%\end{array}$ \\
\hline & $\begin{array}{l}\text { Kegiatan } \mathbf{3} \\
\text { Pendampingan belajar di rumah untuk siswa } \\
\text { berbasis karakter dan nilai-nilai religius. }\end{array}$ & $\begin{array}{l}\text { - Peningkatan kualitas belajar siswa yang } \\
\text { menyenangkan berbasis karakter } \\
\text { - Target capaian } 90 \%\end{array}$ \\
\hline & $\begin{array}{l}\text { Kegiatan } 4 \\
\text { Pendampingan Baca Tulis Alquran (BTQ) } \\
\text { pada TPQ Al Hikmah sebagai pendukung } \\
\text { penguatan internalisasi Karakter }\end{array}$ & $\begin{array}{l}\text { Kegiatan membantu Program TPQ } \\
\text { dalam penguasan BTQ dan karakter } \\
\text { islami } \\
\text { - Partisipasi aktif } 100 \%\end{array}$ \\
\hline Pelaporan & $\begin{array}{llll}\text { Penyusunan laporan akhir dan luaran } \\
\text { kegiatan }\end{array}$ & $\begin{array}{l}\text { - Laporan Pengabdian } 100 \% \\
\text { - Artikel jurnal } 100 \% \\
\text { - Media massa } 100 \% \\
\text { - Video kegiatan } 100 \%\end{array}$ \\
\hline
\end{tabular}

\section{HASIL DAN PEMBAHASAN}

1. Sosialisasi Pendampingan Belajar di Rumah Berbasis Karakter dengan Nilainilai Religius

Sosialisasi bertujuan untuk memberikan pemahaman tentang program pengabdian masyarakat yaitu program pendampingan belajar di rumah berbasis karakter dengan nilai-nilai religius. Sosialisasi ini diikuti oleh kepala dusun, ketua PRM Gonowangi, orang tua wali murid dan tiga guru MI Surodadi 2. Sosialisasi dimulai dengan sambutan Bapak Kepala Dusun dan Ketua PRM Gondowangi. Adapun materi sosialisasi disampaikan Dr. Imam Mawardi 
selaku Ketua PKMT. Materi sosialisasi berkenaan dengan (1) tujuan dan target program pengabdian masyarakat di Dusun Gondowangi, (2) pentingnya pendidikan anak dan tanggung jawab orang tua dalam menanamkan karakter yang baik, (2) pola pendampingan belajar di rumah dengan pembiasaan karakter religius di masa covid 19 .

Penekanan pada pendidikan karakter dengan nilai-nilai religius ini menjadi substansi pendampingan belajar di rumah, khususnya di masa pandemi covid 19. Sebagaimana dikemukakan Mawardi dkk (2019), bahwa nilai karakter sebagai dimensi terdalam pendidikan yang membudayakan dan memberadabkan, yang dibentuk dari nilai-nilai islami berdasarkan misi pendidikan profetik Rasulullah Muhammad SAW. Misi profetik merupakan sistem yang melekat sebagai spirit sekaligus dasar moral pada keseluruhan pelaksananan proses pendidikan. Dalam hal ini, Khairudin dan Susiwi (2013) menjelaskan bahwa karakter yang ditanamkan pada anak sejak dini akan menjadi karakter dan budaya yang kuat dalam membentuk kepribadian anak. Dari sinilah pendampingan berbasis karakter dengan nilai religiusitas dapat tetap diperoleh siswa tanpa harus kehilangan substansi pengetahuan yang harus diperoleh di masa darurat covid 19.

Dari dialog dalam sosialisasi ini, diperoleh data tentang permasalahan yang terjadi dalam pembelajaran di rumah di masa covid 19 , seperti orang tua kesulitan dalam membagi waktu antara bekerja, membimbing anak belajar, dan menyelesaikan pekerjaan rumah siswa; selain itu siswa mengalami kesulitan dalam memahami materi sementara orang tua yang mendampingi belajar tidak mempunyai kemampuan tentang materi tersebut. Apalagi tentang internalisasi karakakter tidak terpikirkan sama sekali dalam proses pendampingan belajar di rumah. Dengan demikian melalui kegiatan pendampingan belajar di rumah berbasis karakter dengan nilai-nilai religius yang dilakukan oleh kelompok Pengabdian Pada Masyarakat Terpadu (PPMT) Universitas Muhammadiyah Magelang bermanfaat kepada orang tua dan siswa, karena dapat memecahkan beberapa permasalahan yang muncul.

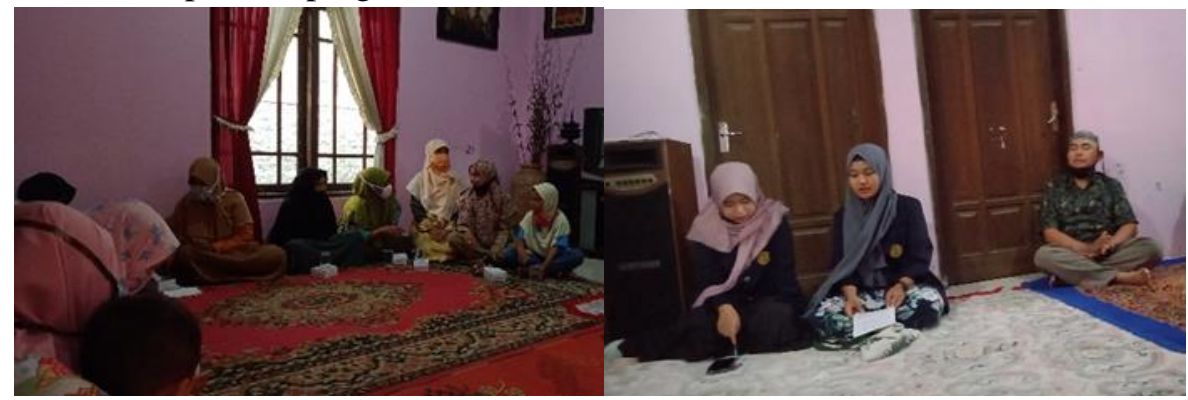

Gambar 1. Sosialisasi Program Pendampingan Belajar

belajar siswa. Karena buku saku ini dapat

\section{Pembuatan Buku Saku Panduan Belajar di Rumah}

Salah satu upaya yang dilakukan guna menyelesaikan permasalahan yang ada, kelompok pengabdian masyarakat membuat buku saku panduan belajar di rumah di masa covid 19 . Buku panduan ini berisi tatacara pendampingan belajar berkarakter dengan nilai religius. Buku ini dilengkapi dengan doa-doa belajar dan panduan mencegah covid 19.

Buku panduan ini bemanfaat bagi orang tua wali murid atau mitra yang mendampingi memandu tentang bagaimana menginternalisasi nilai-nilai karakter religius kepada anak. Orang tua yang mendampingi belajar akhirnya tidak sekedar mendampingi belajar untuk transfer pengetahuan dan keterampilan saja, tapu juga menerapkan nilai-nilai karakter religus kepada anak. Buku saku ini sangat baik sebagai panduan orang tua siswa dalam mendampingi belajar mandiri di rumah di masa pandemi covid 19 maupun di masa normal. 


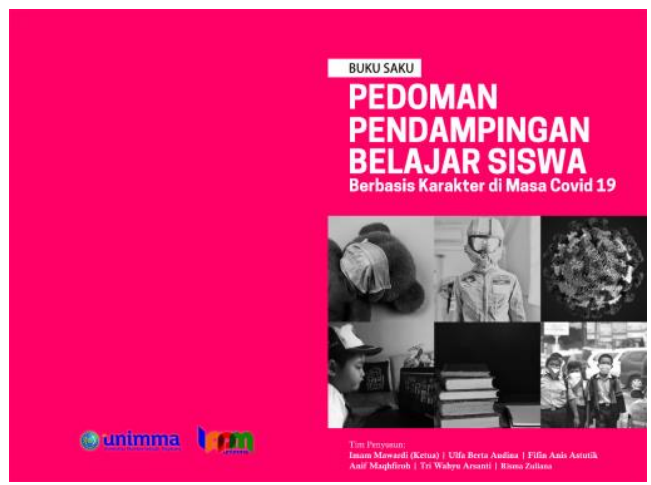

Gambar 2. Cover Buku Saku

\section{Pendampingan Belajar di Rumah Berbasis Karakter dengan Nilai-nilai Religius}

Proses pendampingan belajar di rumah dilakukan selama empat hari dalam satu minggu yaitu setiap hari Senin sampai hari Kamis, yang dimulai pukul 08.30-10.30 WIB untuk kelas 1 s.d kelas 5; danpukul 13.00-15.00 untuk kelas 6 . Penerapan pendampingan yang dilakukan oleh kelompok PPMT diikuti oleh siswa kelas 1-6 MI Surodadi 2 yang berjumlah 70 siswa. Secara tidak terpogram juga mendampingi belajar untuk siswa SMA/SMK. Bentuk pendampingan meliputi penjelasan materi dari tugas sekolah, pendampingan pengerjaan soal dan pemberian motivasi untuk meningkatkan semangat belajar siswa.

Pendampingan dilakukan secara tim, yaitu setiap kelas diampu dari mahasiswa PKMT dan satu dari remaja kader PRM dengan metode bevariasi dan menggembirakan sesuai materi yang sedang dipelajari oleh siswa. Tempat pelaksanaan pendampingan adalah di rumah kepala dusun, di musholla dan di masjid AlHikmah Dusun Penggaron Kidul. Pendampingan dilaksanakan dengan menerapkan protokol kesehatan seperti memakai masker dan selalu mencuci tangan. Pendampingan tidak dilaksanakan di sekolah, karena pada masa pandemi ini sekolah tidak diperbolehkan oleh dinas terkait untuk melakukan proses pembelajaran secara langsung di sekolah, namun melalui pembelajaran sementara di rumah, yatu orang tua/siswa mengambil tugas ke sekolah dan dikerjakan di rumah.

Internalisasi nilai karakter melalui kegiatan pembelajaran mempunyai tujuan agar terbentuk; (1) peserta didik yang memiliki keseimbangan antara kemampuan kognitif dan psikomotorik di satu pihak serta kemampuan afektif di pihak lain, (2) peserta didik yang beriman, bertakwa dan beraklak mulia serta senantiasa menjaga hubungan dengan Tuhan, sesama manusia, dan alam sekitar secara harmonis, (3) peserta didik yang menghargai waktu, memiliki etos kerja tinggi, disiplin, mandiri, berjiwa kewirausahaan untuk mendukung proses pengembangan IPTEK (Muslich, 2011). Pendidikan karakter perlu diadaptasi dalam pendidikan akhlaq, untuk menyiapkan generasi yang berwawasan global dan tidak terbelenggu oleh wawasan lokal yang sempit. Adaptasi tersebut mencakup diantaranya adalah pelibatan orang tua dan masyarakat, wawasan guru dan peran lembaga pendidikan, dan model pembelajaran yang variatif (Sutomo, 2014).

Model internalisasasi karakter dilakukan di awal, tengah, dan akhir dari program pendampingan belajar. Di awal dimulai dengan salam dan dilanjutkan doa sebelum belajar dimulai; di tengah dilakukan saat proses pendampingan melalui nasehat kebaikan dan cerita-cerita yang membangun. Hal ini dilakukan secara fleksibel sehingga tidak mengganggu inti pendampingan. Di akhir pertemuan, siswa dibiasakan dengan doa dan salam untuk mengakhiri pertemuan. Nilai-nilai karakter religius tetap terjaga sebagai pengganti belajar di kelas bersama bapak/ibu guru.

Pendampingan menjadi nilai keunggulan dan antusias masyarakat, karena mampu memenuhi kebutuhan yang hilang dari sistem pembelajaran di masa covid ini, yaitu proses 
internalisasi karakter dengan nilai-nilai religius tetap terjaga, di samping itu pula mampu memecahkan persoalan-persolan yang dihadapi orang tua berkaitan dengan kemampuan ilmu pengetahuan yang dimiliki orang tua.

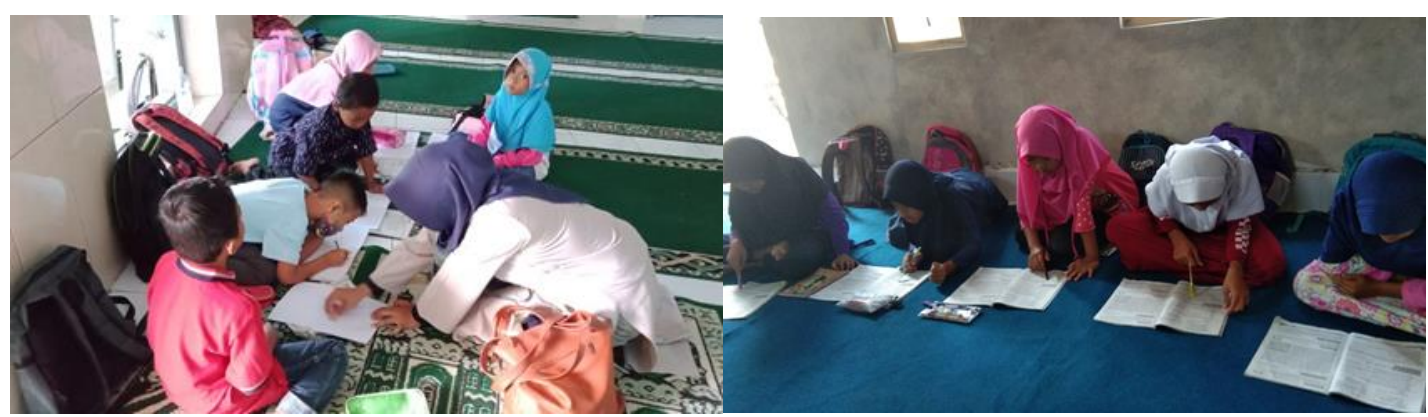

Gambar 3. Pelaksanaan Pendampingan dengan Siswa

\section{Pendampingan Taman Pendidikan Al- Quran (TPQ)}

Keberadaan TPQ sebagai pendidikan nonformal pada dasarnya adalah menjadi jembatan antara pendidikan informal (keluarga) dan penddikan formal (keluarga) dalam mendukung pembelajaran Baca Tulis Al-Quran (BTQ) dan nilai-nilai karakter dasar pada anakanak. Demikian juga untuk membantu program pemerintah menuju tercapainya tujuan Pendidikan Nasional, khususnya dalam sisi penanaman akidah serta pengembangan iman dan takwa juga budi pekerti yang baik (akhlakul karimah). (Priyadi, dkk, 2013).

Program pendampingan TPQ dalam PKMT ini merupakan program pelengkap untuk lebih menguatkan nilai karakter religius siswa. Hal ini berdasarkan kebutuhan kekurangan tenaga pengasuh, dengan rasio 5:80 pengasuh dan santri yang mengikuti TPQ. Program TPQ dilaksanakan di Masjid Al-Hikmah setiap hari Senin dan Selasa, setelah shalat Asyar pada pukul 16.00 WIB sampai selesai. TPQ ini diikuti 80 anak dengan kategori usia penddiikan PAUD dan TK serta kelas 1-6 MI. Santri-santri tersebut tidak hanya berasal dari Dusun Penggaron Kidul saja, namun juga dari dusun sekitarnya. Model pendampingan TPA tidak hanya pada Baca Tulis Al-Quran (BTQ) saja, namun juga materi-materi lain yang mendukung pembelajaran BTQ, seperti hafalan surat-surat pendek, hadist-hadist pendek, bacaan shalat, menyanyikan lagu islami, cerita islami, dan lain sebagainya. Metode yang diterapkan untuk BTQ adalah Iqra' melalui pendampingan santri satu per satu sesuai golongan usia.

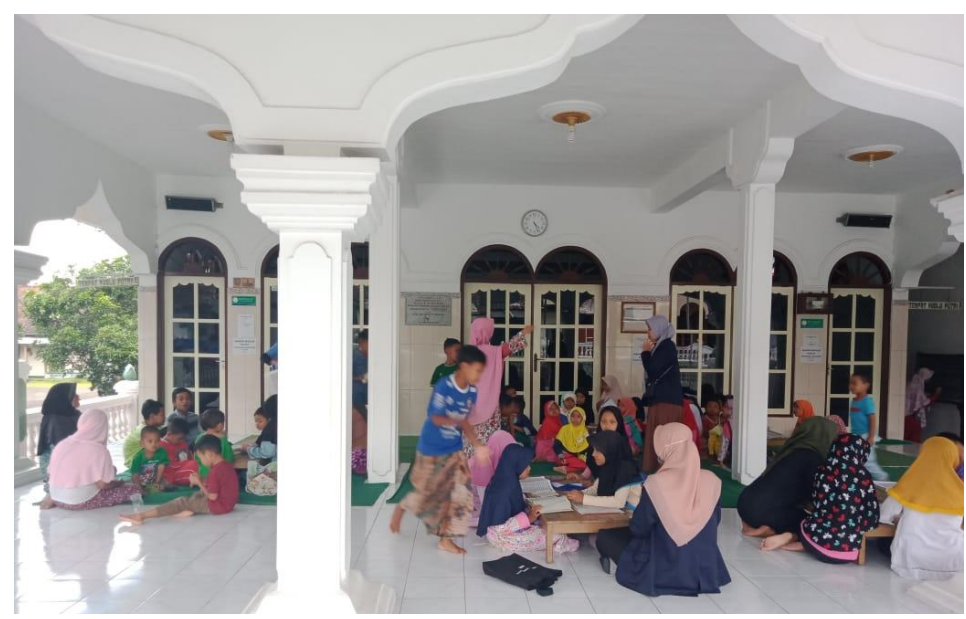

Gambar 4. Pendampingan TPQ 


\section{SIMPULAN DAN SARAN}

Pendampingan belajar di rumah dalam musim pandemi covid 19 sebagai pengganti belajar di sekolah adalah untuk membantu masyarakat yang secara khusus telah dapat (1) mensosialisasikan pentingnya pendidikan karakter di masa covid 19 untuk orang tua wali murid, (2) menyusun buku saku panduan bimbingan belajar di rumah berbasis karakter religious, (3) memberi pendampingan belajar di rumah untuk siswa berbasis karakter dan nilainilai religius, (4) membantu dalam mendampingi santri Baca Tulis Alquran (BTQ) pada TPQ sebagai pendukung penguatan internalisasi karakter. Program pendampingan ini dapat terlaksana dengan baik, meskipun masih harus ditindakalanjuti dan ditingkatkan oleh kader PRM.

Adapun saran berkait dengan pelakasanaan program pendampingan belajar adalah: (1) agar senantiasa digalang kerjasama yang baik antara pihak sekolah, orang tua wali murid dan pihak PRM dalam memecahkan persoalan belajar siswa di musim pandemic covid 19 dan sesudahnya, (2) agar pendidikan karakter berbasisis nilai-nilai religius dapat menjadi pemicu pengembangan prestasi dan kepribadian siswa yang perlu didukung bersama baik oleh pihak sekolah, orang tua, maupum PRM selaku mitra pendidikan di masyarakat, (3) perlunya dukungan dan kebijakan UNIMMA dalam kontribusinya terhadap PRM untuk meneruskan kegiatan pendampingan belajar ini dalam rangka meningkatkan mutu pendidikan yang berkarakter.

\section{UCAPAN TERIMAKASIH (JIKA ADA)}

Ucapan terimakasih disampaikan kepada

(1) Univeristas Muhammadiyah Magelang melalui LPPM atas bimbingannya dan berbagai fasilitas yang diberikan dalam mendukung PPMT ini; (2) Kepala Dusun Penggaron Kidul yang memberi izin dan fasilitas pendampingan belajar di rumah, (3) Kepala MI Muhammadiyah Surodadi 2 yang telah memberikan data dan saran-saran dalam pelaksananaan program PPMT, (4) PRM Gondowangi yang telah menjadi mitra kerjasama yang baik dalam pelaksanan program pendampingan belajar, (5) Seluruh warga Dusun Penggaron Kidul atas bantuan dan dukungannya. Semoga atas jerih payah dan bantuan menjadi leading kebaikan dalam meningkatkan mutu pendidikan yang berkarakter di Indonesia.

\section{DAFTAR PUSTAKA}

Gugus Tugas Percepatan Penanganan COVID-19 Indonesia. (2020), "Data COVID-19 Global dan Indonesia." 2020, [Online]. Available: https://covid19.go.id/.

Khairudin, Moh. dan Susiwi (2013). Pendidikan Karakter Melalui Pengembangan Budaya Sekolah Di Sekolah Islam Terpadu Salman Al Farisi Yogyakarta. Jurnal Pendidikan Karakter, Tahun III, Nomor 1, Februari 2013. Halaman 77-86.

Mawardi, Imam., dkk. (2019). Penguatan Pendidikan Karakter (PPK) Berbasis Budaya Islami Sekolah di MI Muhammadiyah Sidorejo Bandongan. JPPM Jurnal Pengabdian dan Pemberdayaan Masyarakat. Volume 4, No. 1 Maret 2020. ISSN: 2549-8347 (Online), ISSN: 25799126 (Print). DOI: 10.30595/jppm.v0i0.5673.

Muslich, Masnur. (2011). Pendidikan Karakter: Menjawab Tantangan Krisis Multidimensional. Jakarta: Bumi Aksara.

Priyadi, Unggul, dkk. (2013), Peningkatan Mutu Pembelajaran Taman Pendidikan Al-Quran dengan Pembuatan Kurikulum TPA. Jurnal Inovasi dan Kewirausahaan. ISSN: 20893086. Volume 2 No. 3, September 2013 Halaman 204-211.

Pujilestari, Yunita. (2020). Dampak Positif Pembelajaran Online Dalam Sistem Pendidikan Indonesia Pasca Pandemi Covid19. 'Adalah: Buletin Hukum dan Keadilan, ISSN: 2338 4638. Vol. 4, No. 1 (2020). Halaman 49-56.

Sabiq, Ahmad Fikri. (2020). Persepsi Orang Tua Siswa tentang Kegiatan Belajar di Rumah sebagai Dampak Penyebaran Covid 19. Civic-Culture: Jurnal Ilmu Pendidikan PKn dan Sosial Budaya. ISSN 2579-9924 (Online). Volume 4 No.1 July 2020 (Special Issue). Halaman 01-07.

Sutomo, Imam. (2014). Modification of Character Education into Akhlaq Education 
for The Global Community Life. IJIMS, Indonesian Journal of Islam and Muslim Societies, Volume 4, Number 2, December 2014: 291-316.

Suyadi, dkk. (2020). The fiqh of disaster: The mitigation of Covid-19 in the perspective of Islamic education-neuroscience. International Journal of Disaster Risk Reduction $\quad 51 \quad$ (2020) 101848 https://doi.org/10.1016/j.ijdrr.2020.101848. journal homepage: http://www.elsevier.com/locate/ijdrr 